\title{
Detailed Pharmacognostical and Phytochemical Screening of Stem and Stem Bark of Ficus semicordata Buch.-Ham. Ex sm. - An Extra Pharmacopoeial Drug of Ayurveda
}

\author{
Gupta Shashi ${ }^{1, *}$, Acharya Rabinarayan ${ }^{2}$, Harisha CR $^{3}$, Shukla Vinay ${ }^{4}$
}

Gupta Shashi ${ }^{1, *}$, Acharya Rabinarayan ${ }^{2}$, Harisha $\mathrm{CR}^{3}$, Shukla Vinay ${ }^{4}$

'PhD scholar of Dravyaguna, Institute for Post Graduate Teaching and Research in Ayurveda, Gujarat Ayurved University, Jamnagar, INDIA.

${ }^{2}$ Professor \& Head, Department of Dravyaguna, Institute for Post Graduate Teaching and Research in Ayurveda, Gujarat Ayurved University, Jamnagar, INDIA.

${ }^{3}$ Head, Pharmacognostical Laboratory, Institute for Post Graduate Teaching and Research in Ayurveda, Gujarat Ayurved University, Jamnagar, INDIA.

${ }^{4}$ Head, Pharmaceutical Laboratory, Institute for Post Graduate Teaching and Research in Ayurveda, Gujarat Ayurved University, Jamnagar, INDIA.

\section{Correspondence}

Gupta Shashi

Room No. 329, IPGT \& RA, GAU-Jamnagar, INDIA.

Phone no: 9824999823

E-mail: shashi.gpt@gmail.com

History

- Submission Date: 11-12-2018;

- Review completed: 25-05-2019;

- Accepted Date: 22-04-2019.

DOI : 10.5530/pj.2019.11.202

Article Available online

http://www.phcogj.com/v11/i6

Copyright

(c) 2019 Phcogi.Com. This is an openaccess article distributed under the terms of the Creative Commons Attribution 4.0 International license.

\begin{abstract}
Introduction: Stem bark of Bhumi udumbara (Ficus semicordata Buch.-Ham. ex Sm.) is used traditionally in the treatment of leprosy, ulcer, dysentery, wound, pregnancy, complaints of gastric, liver, bladder and various disorders. In present study, stem and stem bark of $F$. semicordata are explored for their microscopic including powder microscopy, physiochemical and preliminary phytochemical aspects. Materials and Methods: Stem and stem bark of the plant, after proper authentication by BSI Kolkata, were evaluated following standard procedures. Results: Stem is hard, cylindrical, cut pieces measures about $10-25 \mathrm{~cm}$ in length and $0.4-$ $0.8 \mathrm{~cm}$ in diameter. Diagrammatic transverse section of stem shows outer cork followed by wide parenchymatous cortex with prismatic and rhomboidal crystals, starch grains and tannin content. Powder light brown in colour; odour woody; taste tasteless to astringent; texture fibrous. Stem bark is hard, single quilled after drying, outer dark reddish brown in colour with presence of lenticels, longitudinal cut fibres, rough in surface. Diagrammatic section, of the bark, shows outer several layered cork followed by cortical region along with medullary rays. Powder tortilla(brown) in colour; odour slightly aromatic; taste astringent; texture fibrous. Loss on drying at $110^{\circ} \mathrm{C}$ was found to be $7.41 \%$ and $8.60 \%$ of stem and stem bark respectively. HPTLC results shows 3 peaks and 0 peak at 254 and $366 \mathrm{~nm}$ of stem and 3 peaks at 254 and $366 \mathrm{~nm}$ of stem bark respectively. Discussion and Conclusion: Woody stem and presence of brown content, tannin, rhomboidal and prismatic crystals in stem and stem bark are the diagnostic characters.
\end{abstract}

Key words: Anukta dravya, Bhu-udumbara, Bhuindumer, Extra-pharmacopoeial, Ficus semicordata.

\section{INTRODUCTION}

Folklore medicines involves medicinally important plants and are one of the major area of new drug discovery, in drug research. Detailed pharmacognostical evaluation, as a part of drug standardization, provides valuable information regarding the morphology, microscopical and physical characters of a crude drug. ${ }^{1}$ A folklore plant of Moraceae family Bhui dumri, is being used by tribals of Odisha. ${ }^{2}$ It is a small or medium-sized evergreen tree, having oblong or semi-saggitate leaves, hispid above, petioles-scabrid, receptacles in pairs or clusters on leaflets, drooping branches, ripens reddish-brown ${ }^{3}$ and is distributed along sub-Himalayan forests from Chenab to Manipur, ascending up to $300 \mathrm{~m}$, West Bengal, Odisha, Chota Nagpur, Central India, Bangladesh (Chittagong), Myanmar, being cultivated in the valleys, ravines and on the banks of streams. ${ }^{4}$ Stem bark of the plant has been reported extensively for its use in the treatment of leprosy, ulcer, dysentery, wound, pregnancy, complaints of gastric, liver and bladder, visceral obstruction, baldness, toothache, diarrhea, boil and menstrual disorder. ${ }^{5}$

Though various parts of plants are used by tribals, the plant is not yet evaluated in a scientific way for its pharmacognistical characters and phytochemical constituent. Hence, stem and stem bark of $F$. Semicordata has been explored, in this article, to bring insight on the pharmacognistical characters, preliminary phytochemical constituents including High Performance Thin Layer Chromatography (HPTLC) profile.

\section{MATERIALS AND METHODS}

\section{Collection and preservation of the sample}

Ficus semicordata Buch.-Ham. ex Sm. (Moraceae) locally known as Bhui dumri, was identified from its natural habitat Paikmal, Odisha, during November 2017. Its stem and stem bark were collected and authenticated by local taxonomist with the help of botanical flora. ${ }^{2}$ A sample specimen was preserved in Pharmacognosy laboratory of IPGT and RA Jamnagar (SPECIMEN NO- IPGT and RA. Phm. 6249/17-18) and also authenticated by the Botanical Survey of India (Cetificate no. CNH/Tech. II/2018/11). The sample was preserved in a solution prepared from $70 \%$ ethyl alcohol: glacial acetic acid: formalin (AAF) in the ratio of 90:5:5. ${ }^{6}$

\section{Chemical and reagents}

Chemicals utilized for pharmacognostical study were procured from Sigma-Aldrich. Mumbai, India and

Cite this article: Shashi G, Rabinarayan A, Harisha CR, Vinay S. Detailed Pharmacognostical and Phytochemical Screening of Stem and Stem Bark of Ficus semicordata Buch.-Ham. Ex sm. - An Extra Pharmacopoeial Drug of Ayurveda. Pharmacog J. 2019;11 (6):1303-11. 
other reagents or chemicals used were of standard grade or analytical grade.

\section{Pharmacognostical study}

\section{Macroscopic Study}

Macroscopic observations were made with naked eyes and with the help of dissecting microscope. The samples were cleaned properly and macroscopic study of the stem and stem bark were carried out with help of Quasmo binocular compound microscope.

\section{Organoleptic}

Raw samples were evaluated for their various characters like, colour, texture, odour, taste etc. ${ }^{7}$

\section{Microscopic evaluation}

Free hand sections of various parts of stem and stem bark were taken. First observed in distilled water and then stained with phloroglucinol and Conc. HCl. Photographs were also taken by using microscope, attached with Kodak easy share C140, 8.2 megapixels 3x optical/5x digital zoom HD camera. ${ }^{8}$

\section{Powder microscopy}

Powder of stem and stem bark were scrutinized with and without staining and microphotographs were taken under Carl Zeiss trinocular microscope attached with Kodak easy share C140, 8.2 megapixels $3 x$ optical/5x digital zoom HD camera.

\section{Physicochemical parameters and qualitative analysis}

The powder of stem and stem bark were evaluated for physico-chemical i.e. $\mathrm{pH}$, loss on drying, total ash value, water soluble extractive value and alcohol soluble extractive value, following protocols recommended by Ayurvedic pharmacopoeia of India (API). ${ }^{9}$ For qualitative analysis, the presence of various secondary metabolites dissolved in water and alcohol extract was carried out following standard procedures. ${ }^{10-12}$

\section{High Performance Thin Layer Chromatography (HPTLC)}

Methonalic extract of stem and stem bark were exposed to HPTLC study. ${ }^{13}$ The solvent system used for the study is Chloroform: Ethyl Acetate: Formic Acid(5:4:3 v/v)

\section{Chromatographic conditions}

Application mode was Camag Linomat V, Development Chamber used was of Camag Twin trough Chamber. Precoated Silica Gel 60F 254 plates were used. Chamber Saturation was done for $30 \mathrm{~min}$. Development Time was $10 \mathrm{~min}$. the plate was scanned in CAMAG TLC Scanner 3 with D2 and W lamp, Tungstan Lamp as detectors and Win cats software was used for data analysis.

\section{Spray reagent}

$1 \%$ vanillin sulphuric acid $(40+10)$ (Rankem, USA). The plate was derivatized by $1 \%$ Vanillin sulphuric acid and then heated in hot air oven at $105^{\circ} \mathrm{C}$ till complete colour development.

\section{RESULTS}

\section{Stem}

\section{Macroscopy}

Stem is hard, cylindrical, cut pieces measuring about $10-25 \mathrm{~cm}$ in length and $0.4-0.8 \mathrm{~cm}$ in diameter. Outer surface reddish brown colour with smooth surface and presence of lenticels, nodes and internodes are prominent. Inner surface dark brown with smooth surface, later on become hollow, longitudinal fibres present. Fracture is short and fractured surface is creamish. Formation of false pith in the centre. Odour characteristic (Figure 1a).

\section{Organoleptic characters}

Color externally reddish brown, internally dark brown; odour characteristic; taste astringent.

\section{Microscopic Study: Transverse section of stem}

Diagrammatic transverse section of stem shows outer cork followed by wide parenchymatous cortex with prismatic and rhomboidal crystals of calcium oxalate, starch grains and tannin contant. Vascular bundles were open and collateral. Central part of the stem section occupied by large circular parenchymatous pith (Figure 1b).

\section{Cork}

Cork cells are tangentially elongated compactly arranged with brown content and of 5-7 layers. Where the epidermis situated at the cork region exhibit simple trichomes. Some of the cells consist of prismatic crystal of calcium oxalate (Figure 1c).

\section{Cortex}

Cortex situated beneath the cork, just beneath the cork several layered hypodermis made up of collencyma cells which gives the mechanical support. Rest of the cortex region occupied by parenchyma cells are loaded with prismatic and rhomboidal crystal of calcium oxalate and tannin content. Some of the laticiferous ducts are also observed in the parenchymatous zone. Discontinuous groups of 5-7 layer of pericyclic fibres also circularly arranged all over the cortex region (Figure 1d).

\section{Endodermis}

Endodermis is single layered, made up of parenchyma cells.

\section{Vascular bundle}

Vascular bundle open and collateral, phloem situated above the xylem made up of sieve plates and its fibres. Isolated pericyclic fibres are distributed in between the phloem region. Xylem radially arranged, protoxylem towards the pith and metaxylem towards the cortex. Xylem consists of xylem parenchyma and its fibres. Some of the xylem vessels are intraxylary pitted and also filled with tannin contant. Medullary rays uniseriate - tetraseriate filled with starch grains and prismatic crystals (Figure 1e-i).

\section{Pith}

Pith is made up of parenchyma cells adjacent to the xylem. Some of the parenchyma cells pitted and lignified. Pith cells prismatic crystal, starch grains and brown content later on the pith withdraws and make stem hollow (Figure 1j).

\section{Powder microscopy of stem powder}

\section{Organoleptic characters}

Powder colour is light brown; odour, woody; taste, tasteless to astringent; texture, fibrous.

Diagnostic powder characters of stem shows presence of starch grains, spiral vessel, pitted vessel, simple fibers, pitted stone cell, stone cell, cork in tangential view, fragment of bordered pitted vessel, brown content, rhomboidal crystals, trichome, epidermal cells with tannin content, prismatic crystals, group of lignified stone cells, group of lignified fibers (Figure 2a-p). 


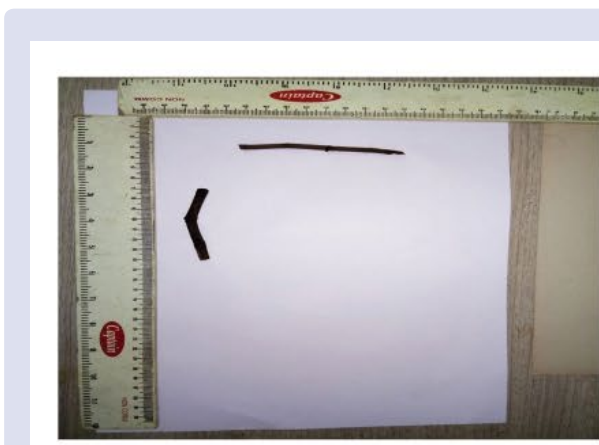

Fig. 1a

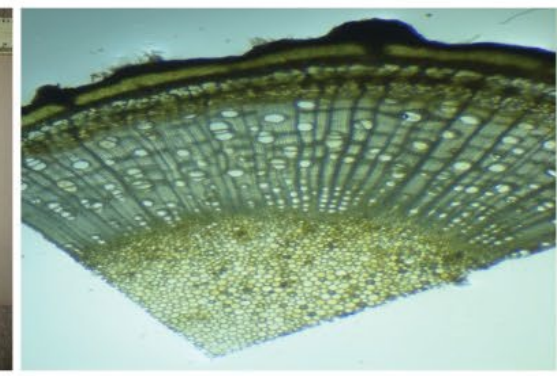

Fig. $1 b$

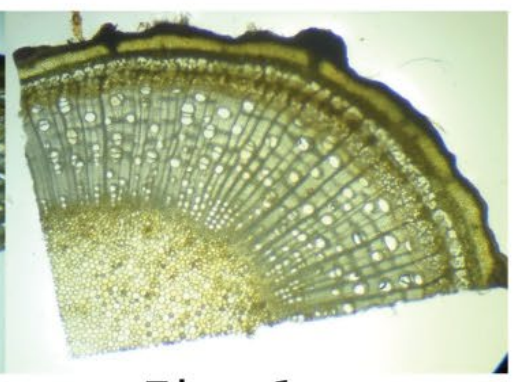

Fig. 1c

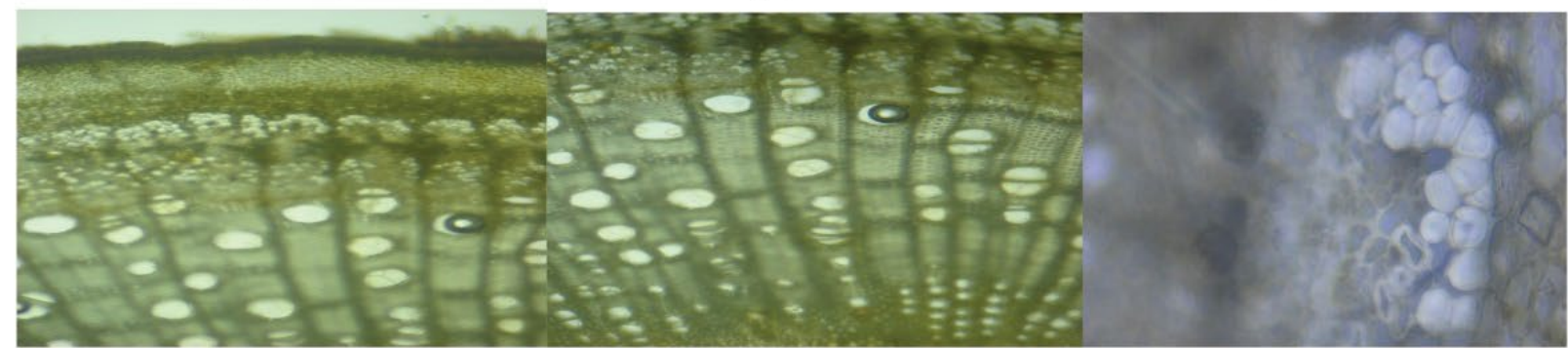

Fig. 1d Fig. 1e

Fig. $1 \mathbf{f}$

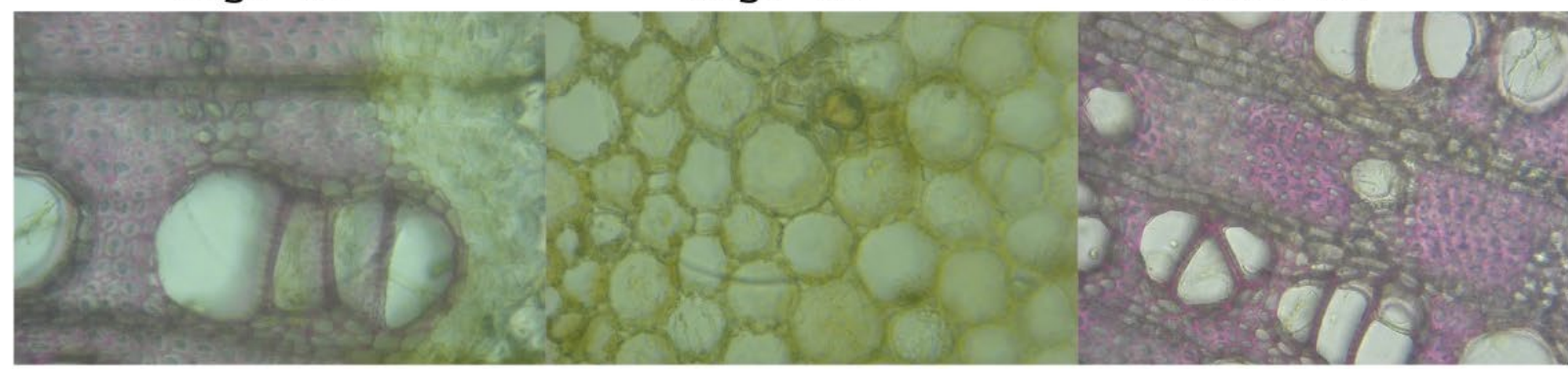

Fig. 1g

Fig. Ih

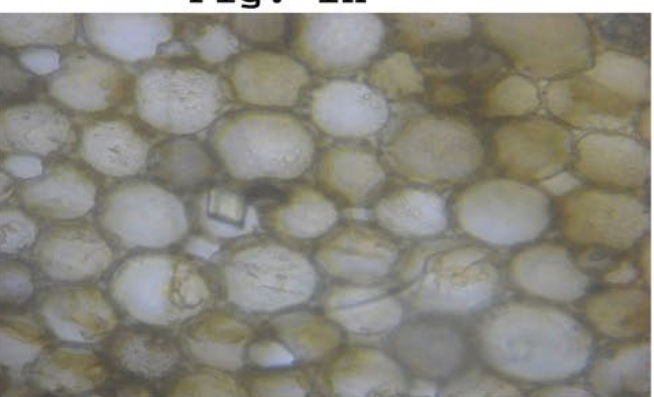

Fig. 1j
Fig. $1 i$

Figure 1: (1. a.) Measurement of fresh Stem, (1. b.) Cork, Cortex, Pith, (1. c.) Epidermal layer, phloem, xylem and medullary rays, (1. d.) Collenchyma parenchyma, pericyclic fiber, (1.e.) Phloem, xylem and medullary rays, (1. f.) Prismatic crystal, pericyclic fiber and phloem, (1. g.) Xylem, xylem fiber, xylem parenchyma and medullary rays, (1. h.) Pitted parenchyma with brown content, (1. i.) Triseriated medullary rays, (1. j.) Pith with prismatic crystals and parenchyma.

\section{Stem bark}

\section{Macroscopic study}

Bark is hard, single quilled after drying, outer dark reddish brown with presence of lenticels, longitudinal cut fibres, rough in surface. Inner surface slightly smooth, reddish brown, fibrous, single channel, smell slightly aromatic/sweetish. fracture is short, fractured surface is creamish. (Figure 3a)

\section{Organoleptic characters}

Colour, outer dark reddish brown and inner reddish brown; odour, aromatic/sweetish; taste, astringent.

\section{Microscopic Study: Transverse section of Stem Bark}

Diagrammatic section of the bark shows outer several layered cork followed by cortical region along with medullary rays.

Detailed T.S of stem bark shows, cork forming the outermost tissue, formed of two to three or five rows of rectangular cells. The cell walls are considerably thick and there is only a marrow lumen in the centre of the cell. The phellogen consists of a single row of thin walled, colourless cubical to rectangular cells and just within the phellogen is a phelloderm of three to four or more rows of thin walled rectangular cells of the same size as the phellogen cells. Some of these cells contain small rhomboidal and prismatic crystals of calcium oxalate and a few 


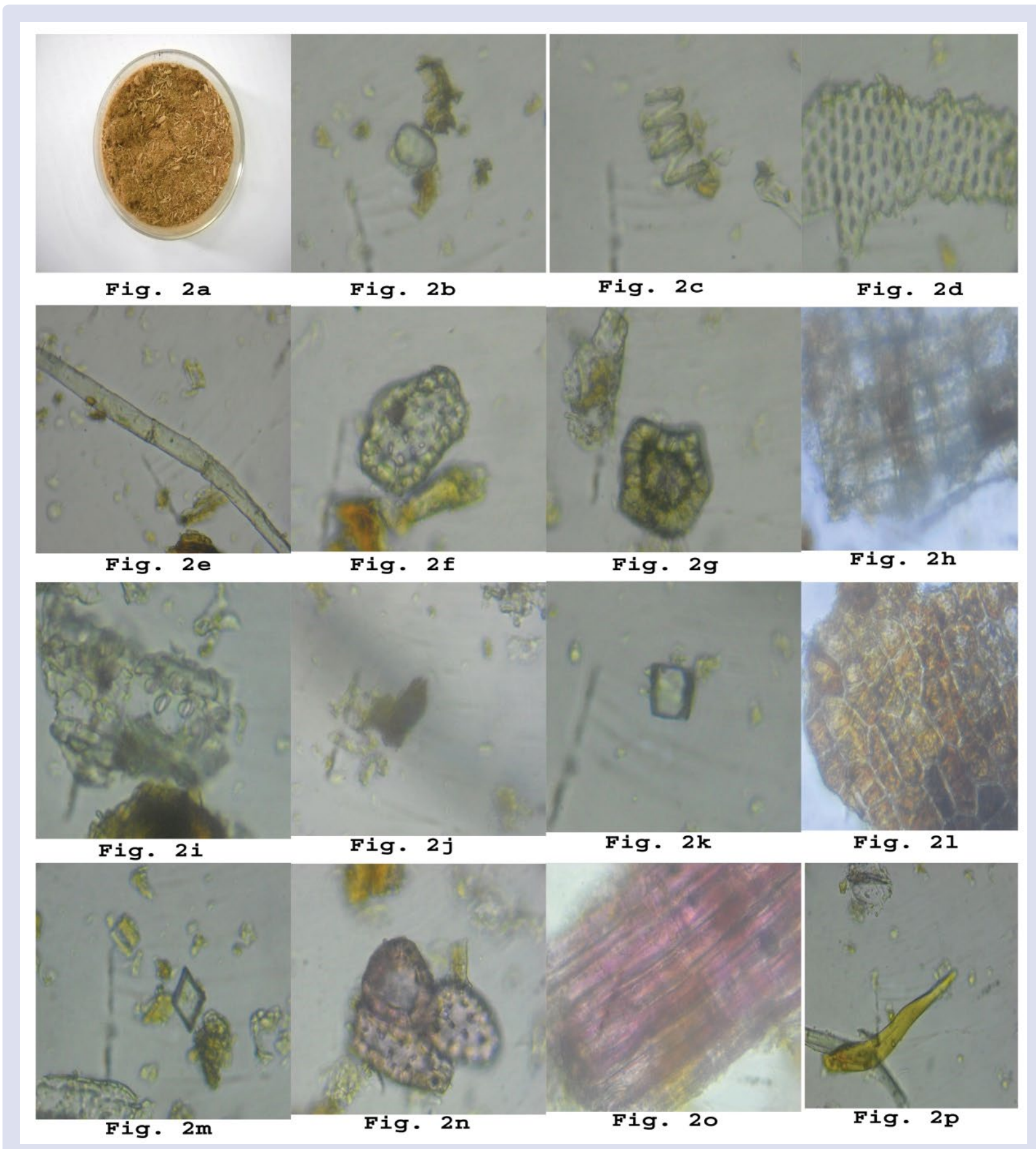

Figure 2: (2. a.) Dried stem powder, (2. b.) Starch grains, (2. c.) Spiral vessel, (2. d.) pitted vessel, (2. e.) simple fibers, (2. f.) pitted stone cell, (2. g.) stone cell, (2. h.) cork in tangential view, (2. i.) fragment of bordered pitted vessel, (2. j.) brown content, (2. k.) rhomboidal crystals, (2. I.) epidermal cells with tannin content, (2. m.) prismatic crystals, (2. n.) group of lignified stone cells, (2. o.) group of lignified fibers, (2. p.) trichome.

cells of the innermost row of this layer contain small chloroplasts. Next, continuous zone of compactly arranged small sized sclereids and stone cells, the cells appearing rectangular or slightly tangentially elongated in T.S. Many of them contain chloroplasts. (Figure 3b-d)

Inner to this zone of sclereids and stone cells are several scattered closely spaced groups of large sized stone cells. These however do not form a continuous zone. The stone cells vary in size and shape and are devoid of chloroplasts. The parenchymatous cells in between the sclereids group as well as those situated inside are rectangular and tangentially elongated and thin walled. Some of these cells contain a reddish-brown colouring matter and others contain starch grains. The cut ends of a number of lactiferous elements can be made out in this region. (Figures 3f-h).

The inner bark forms almost half the thickness of the entire bark. At the periphery of the inner bark a few small sized stone cells and a few thick-walled sclerenchyma cells occur amidst the parenchyma cells. The stone cell, are rounded with wide lumen and are pitted, smaller than those of the middle bark, but are not very thick walled. A very limited of parenchyma cells contain small rounded starch grains or rhomboidal crystals of calcium oxalate. Collapsed elements of phloem 


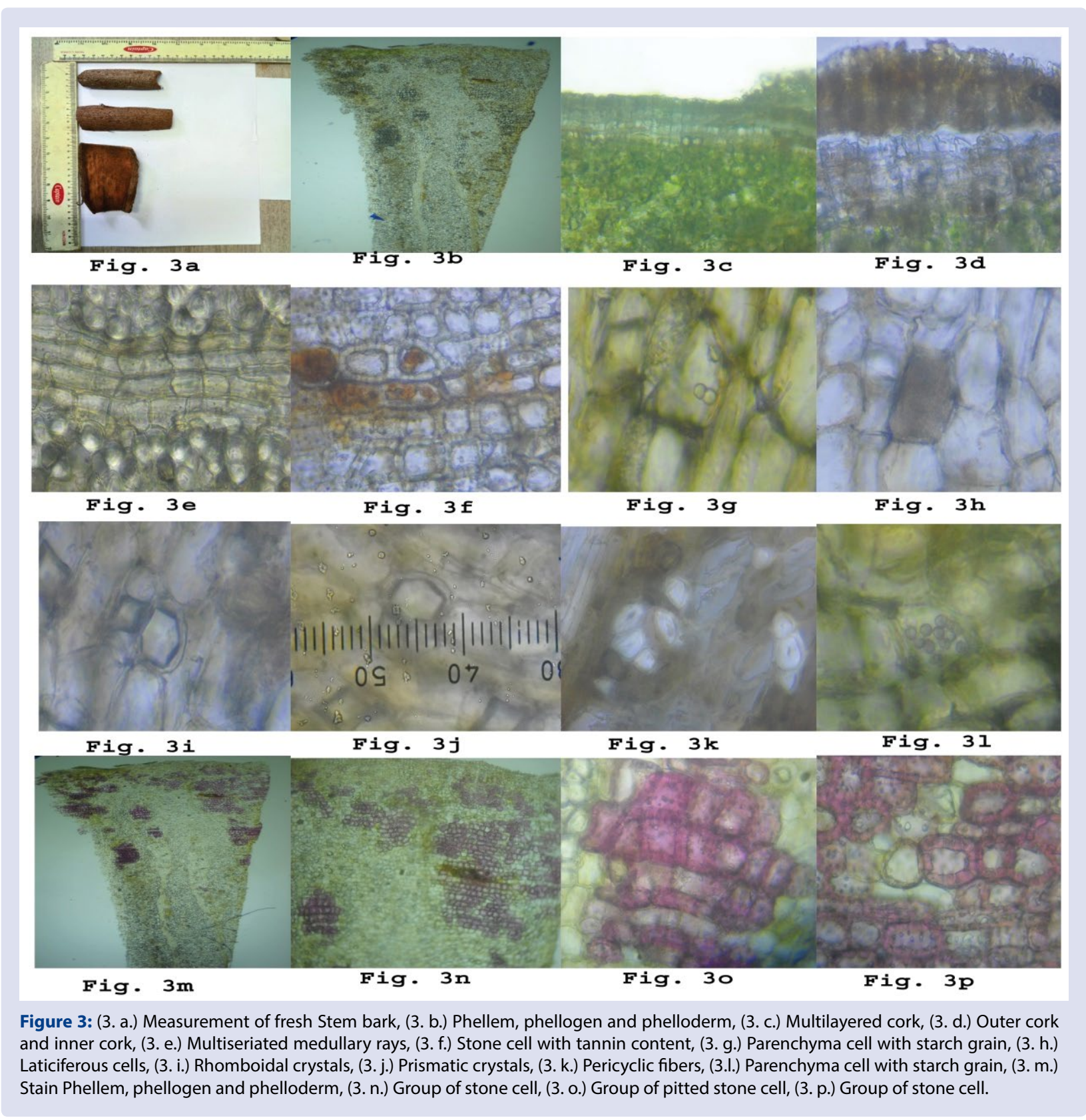

are found in between the other cells in the older peripheral portion. Reddish contents were also present. Towards the inside of the bast also narrow strips of collapsed or obliterated tissue occur alternating with the regular phloem tissue. Solitary sclerenchyma cells occur scattered in this region and also with many pitted stone cells. Cut ends of latex cells are present. The most recently formed phloem is devoid of any thick walled element. It is composed of sieve tubes and companion cells and small and large thin walled, polygonal, parenchyma cells. Some of the smaller parenchyma cells contain the reddish contents. (Figure 3ip).

\section{Medullary rays}

Many, long, wavy and 4 to 6 seriate. They extend up to the middle bark. The ray cells are thin walled and radially elongate towards the inside but become larger as the ray passes from the phloem tissue upwards to the middle bark. Some of the ray cells in the phloem portion contain small rhomboidal as well as rosette crystals of calcium oxalate, while the ray cells at the upper region contain small spherical starch grains. (Figure 3e)

\section{Powder microscopy of Stem Bark powder}

\section{Organoleptic characters}

Powder is tortilla(brown) in colour; odour slightly aromatic; taste astringent; texture fibrous.

Diagnostic powder characters of bark shows presence of fibers passing through medullary rays, pitted stone cells, prismatic crystals, simple fibers, corking surface view, rhomboidal crystals, latex content, brown content, pitted stone cell with wide lumen, crystal fiber, starch grain, group of lignified stone cells, lignified stone cell, iodine stained starch grain. (Figure $4 \mathrm{a}-\mathrm{o}$ )

\section{Physico-chemical analysis}

The results of the physico chemical analysis are being presented in Table 1. Loss on drying of stem and stem bark at $110^{\circ} \mathrm{C}$ is $7.41 \%$ and $8.60 \%$ 


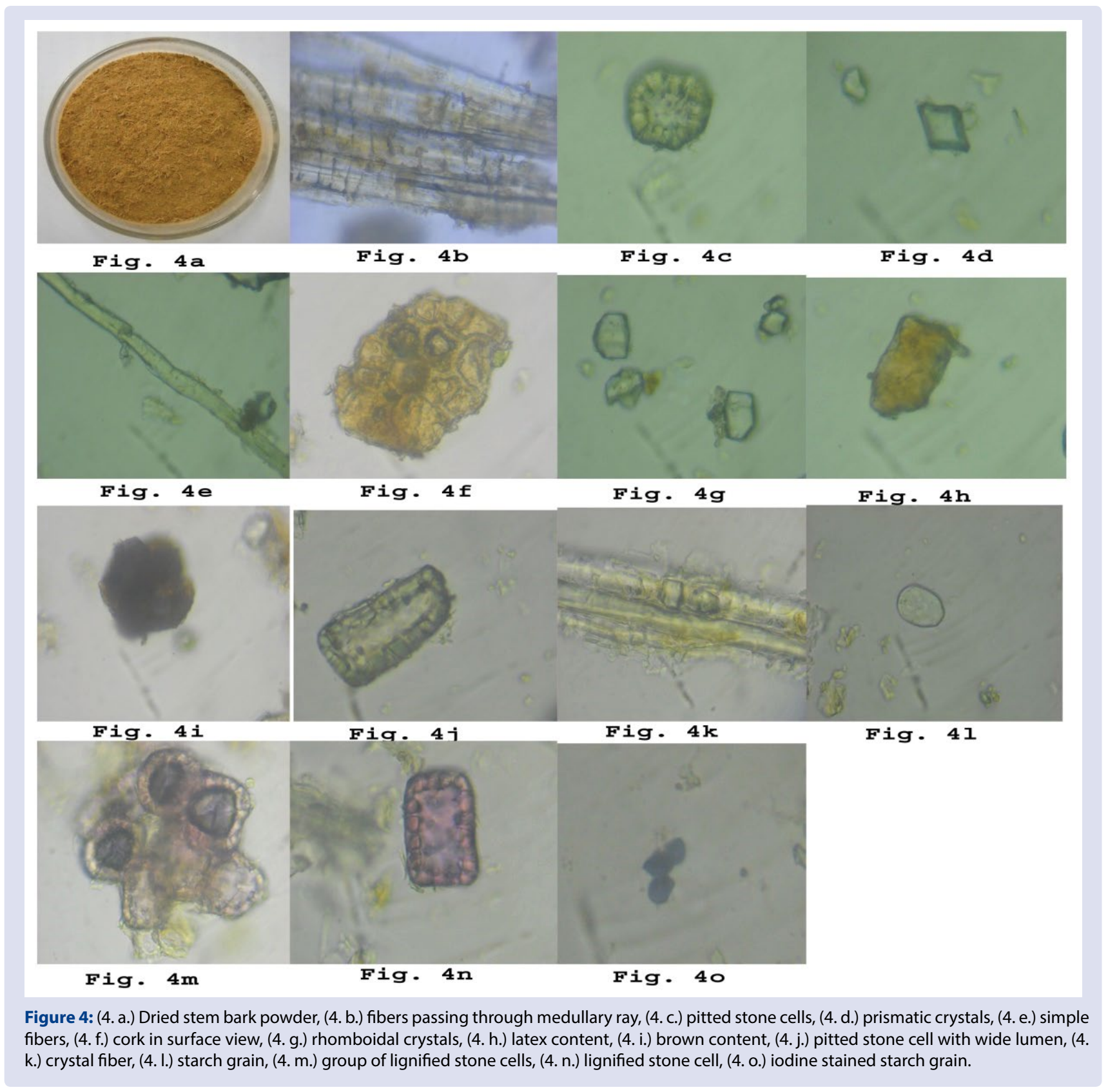

respectively. The methanol and water soluble extract are more in stem than stem bark.

\section{Qualitative tests}

Details of the result after qualitative analysis of stem and stem bark is being presented in Table 2. Presence of tannin, reducing sugar, glycoside, alkaloids, carbohydrate, phenolic compounds and steroid in aqueous as well as methanolic extract of stem and stem bark whereas flavonoids only present in the aqueous as well as methanolic extract of stem.

\section{HPTLC}

The obtained $\mathrm{R}_{\mathrm{f}}$ values are mentioned in Table 3. The methanol extract of stem shows 3 peaks and 0 peaks at 254 and $366 \mathrm{~nm}$ respectively, whereas, the methanol extract of stem bark shows 3 peaks at 254 and $366 \mathrm{~nm}$ respectively. Similar spectra of stem at $0.31 \mathrm{R}_{\mathrm{f}}$ and stem bark at $0.36 \mathrm{R}_{\mathrm{f}}$ was observed.

\section{DISCUSSION}

Stem, primary cortex, extensively sclerosed and outermost layer of the cortex made of cork is the character of Ficus. ${ }^{14}$ Medullary rays uniseriate - tetraseriate filled with starch grains and prismatic crystals in Ficus semicordata whereas uni- to biseriate medullary rays in Ficus retusa L. and Ficus pandurata Hance. ${ }^{15,16}$ Pith cells contain prismatic crystal, starch grains and brown content later on the pith withdraws and make stem hollow whereas pith cells contain cluster and prismatic crystals of calcium oxalate in Ficus retusa and Ficus pandurata. ${ }^{15,16}$

Stem bark is hard, single quilled after drying whereas recurved and channeled quilled in Ficus racemosa, ${ }^{17}$ curved and quilled in Ficus virens ${ }^{18}$ and single quilled in Ficus exasperate. ${ }^{19}$ The cork, outermost tissue is seen to be formed of very few 2-5 rows of rectangular cells whereas it is formed of several rows (8-13 layers) of tabular to subrectangular cells in Ficus pandurata, ${ }^{16} 2$ layers of thickly suberised cells in Ficus racemosa, ${ }^{17}$ 6-10 rows of rectangular radially arranged 


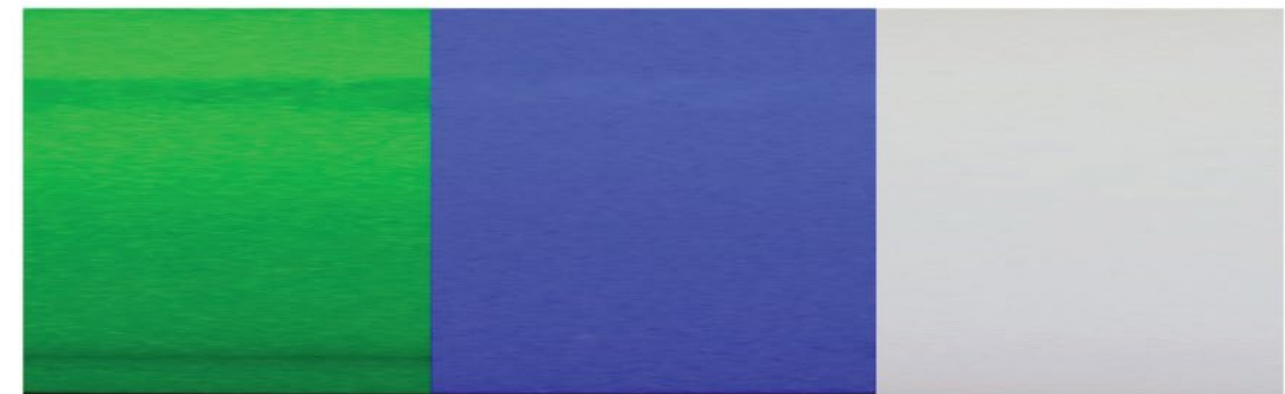

Fig. $5 a$

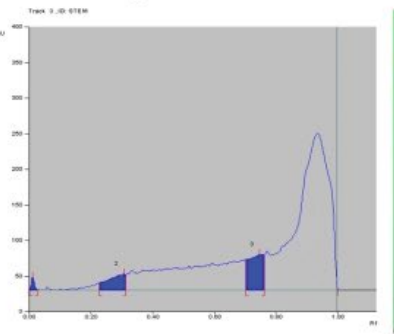

Fig. $5 e$

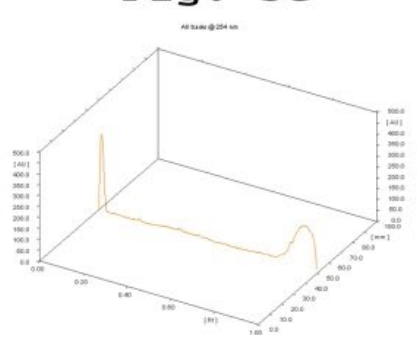

Fig. $5 i$
Fig. $5 b$

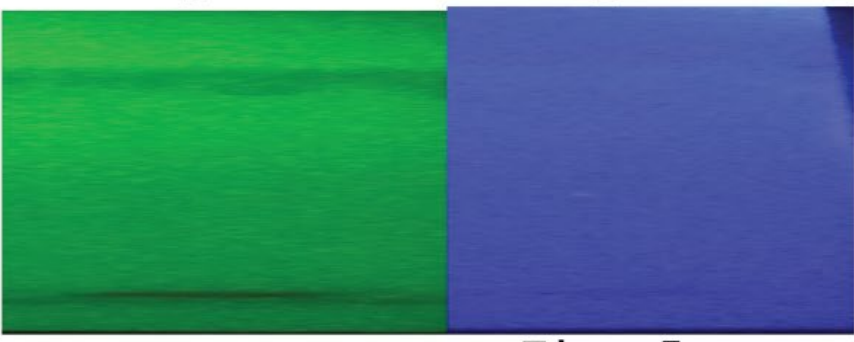

Fig. $5 \mathrm{f}$

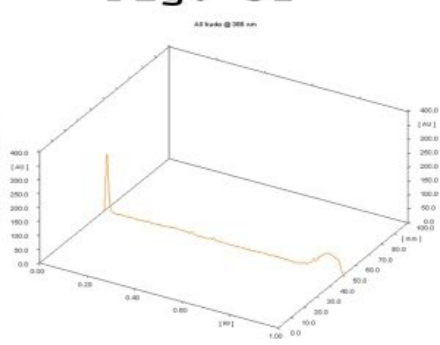

Fig. $5 j$
Fig. 5g

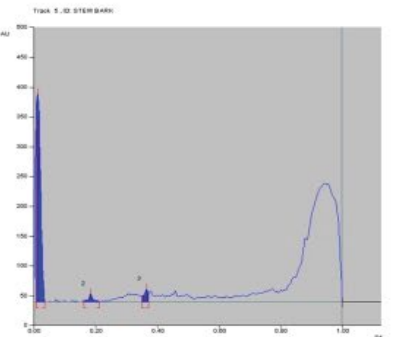

Fig. $5 \mathrm{k}$

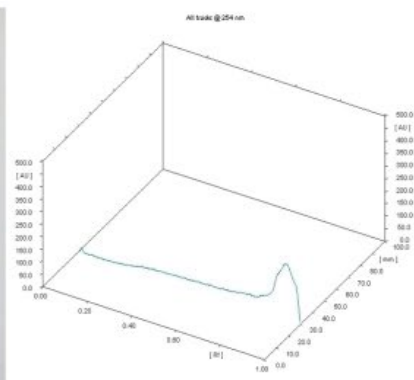

Fig. $5 d$

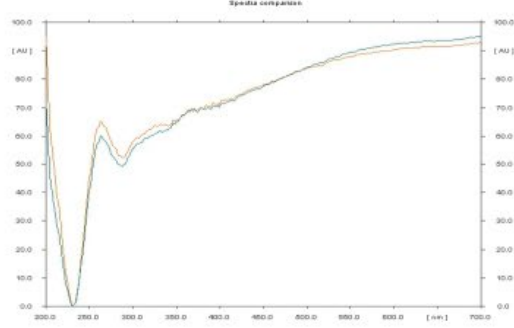

FIg - 5m

Figure 5: (5. a.) HPTLC plate of stem at $254 \mathrm{~nm}$, (5. b.) HPTLC plate of stem at $366 \mathrm{~nm}$, (5. c.) HPTLC plate of stem in UV-VIS range, (5. d.) 3D display of stem at $254 \mathrm{~nm}$, (5. e.) Peak display of stem at $254 \mathrm{~nm}$, (5. f.) HPTLC plate of stem bark at $254 \mathrm{~nm}$, (5. g.) HPTLC plate of stem bark at $366 \mathrm{~nm}$, (5. h.) HPTLC plate of stem bark in UV-VIS range, (5. i.) 3D display of stem bark at $254 \mathrm{~nm}$, (5. j.) 3D display of stem bark at $366 \mathrm{~nm}$, (5. k.) Peak display of stem bark at $254 \mathrm{~nm}$, (5. I.) Peak display of stem bark at $366 \mathrm{~nm},(5 . \mathrm{m}$.) Spectral comparison stem(0.31 Rf) and stem bark.

Table 1: Physico chemical parameters of stem and stem bark powder of $F$. Semicordata.

\begin{tabular}{cccc}
\hline Sr. no. & Test & Result (Stem) & Result (Stem bark) \\
\hline 1. & $\begin{array}{c}\text { Loss on drying at } \\
\mathbf{1 1 0}{ }^{\circ} \mathrm{C}(\% \mathrm{w} / \mathrm{w})\end{array}$ & $7.41 \%$ & $8.60 \%$ \\
2. & $\begin{array}{c}\text { Ash value }(\% \mathrm{w} / \mathrm{w}) \\
\text { Water soluble } \\
\text { extract }(\% \mathrm{w} / \mathrm{w})\end{array}$ & $3.64 \%$ & $3.19 \%$ \\
3. & $\begin{array}{c}\text { Methanol soluble } \\
\text { extract }(\% \mathrm{w} / \mathrm{w})\end{array}$ & $8.96 \%$ & $1.7 \%$ \\
4. & $\mathbf{p H}$ & 6.5 & $1.28 \%$ \\
5. & & & 7.0 \\
\hline
\end{tabular}


Table 2: Results of qualitative analysis of $F$. semicordata stem and stem bark.

\begin{tabular}{|c|c|c|c|c|c|c|}
\hline Sr. No. & Test for & Applied test & $\begin{array}{l}\text { Water extract } \\
\text { (Stem) }\end{array}$ & $\begin{array}{c}\text { Water extract } \\
\text { (Stem bark) }\end{array}$ & $\begin{array}{c}\text { Alcohol extract } \\
\text { (Stem) }\end{array}$ & $\begin{array}{c}\text { Alcohol extract } \\
\text { (Stem bark) }\end{array}$ \\
\hline 1. & Tannin & Lead acetate & + & + & + & + \\
\hline 2. & Reducing sugar & Fehling's test & + & + & + & + \\
\hline 3. & Glycoside & $\begin{array}{c}\text { Keller-Killiani } \\
\text { Test }\end{array}$ & + & + & + & + \\
\hline \multirow{2}{*}{$\begin{array}{l}4 . \\
5 .\end{array}$} & Amino acid & Ninhydrin test & - & - & - & - \\
\hline & Flavonoids & Lead acetate test & + & - & + & - \\
\hline \multirow[t]{2}{*}{6.} & \multirow[t]{2}{*}{ Alkaloids } & Dragondorff's test & + & + & + & + \\
\hline & & Wagner's test & + & + & + & + \\
\hline 7. & Carbohydrate & Molish test & + & + & + & + \\
\hline 8. & $\begin{array}{l}\text { Phenolic } \\
\text { compounds }\end{array}$ & Lead acetate & + & + & + & + \\
\hline 9. & Steroid & Salkowaski test & + & + & + & + \\
\hline \multirow{2}{*}{10.} & \multirow{2}{*}{ Saponin } & Foam Test & - & - & - & - \\
\hline & & Lead acetate test & - & - & - & - \\
\hline 11. & Protein & Biuret's test & - & - & - & - \\
\hline
\end{tabular}

[+: Present, -: Absent]

Table 3: Rf values obtained at short UV light $(254 \mathrm{~nm})$ and long UV light (366nm) of F. semicordata stem and stem bark.

\begin{tabular}{ccccc}
\hline Sr. No. & Rf at $254 \mathrm{~nm}($ Stem) & Rf at 254 nm (Stem bark) & Rf at $366 \mathrm{~nm}$ (Stem) & Rf at $366 \mathrm{~nm}$ (Stem bark) \\
\hline 1. & 0.01 & 0.01 & - & 0.01 \\
2. & 0.31 & 0.18 & - & 0.36 \\
3 & 0.75 & 0.36 & - & 0.88 \\
\hline
\end{tabular}

suberized cells in Ficus virens. ${ }^{18}$ The phellogen consists of a single row of thin walled, colourless cubical to rectangular cells whereas continuous layer of tangentially elongated and thin walled cells in Ficus racemosa. ${ }^{17}$ Phelloderm is made of three to four or more rows of thin walled rectangular cells of the same size as the phellogen cells whereas consisted a few layers of parenchymatous cells, some of the cells contained numerous chloroplasts, while a few others showed thick walled fibers in Ficus racemosa. ${ }^{17}$ Medullary rays long, wavy, 4 to 6 seriate, extend up to the middle bark, in the phloem portion contain small rhomboidal as well as rosette crystals of calcium oxalate and at the upper region contain small spherical starch grains whereas funnel-shaped medullary rays, formed of thin walled elongated parenchyma cells traversing the phloem parenchyma in Ficus pandurata $;{ }^{16}$ multiseriated medullary rays in Ficus virens. ${ }^{18}$ The results obtained from physicochmeical parameter, qualitative and HPTLC study will serve as standardization values providing information regarding the authentification of the plant $F$. semicordata stem and stem bark.

\section{CONCLUSION}

Ficus semicordata is a small or medium-sized evergreen tree. Stem outer surface reddish brown colour with presence of lenticels, nodes and internodes; stem bark is hard, single quilled after drying is the key identifying character. Pharmacognostical, physicochemical results, phytochemical and HPTLC results will help in further validation and act as ideals for quality assertion.

\section{ACKNOWLEDGEMENT}

The authors express sincere gratitude to Head-Pharmacognostical laboratory, Head-Pharmaceutical laboratory and to Director of Institute for Post Graduate Teaching and Research in Ayurveda, Gujarat Ayurved University-Jamnagar

\section{CONFLICT OF INTEREST}

None.

\section{REFERENCES}

1. Agarwal A. Critical issues in quality control of herbal products. Pharma Times. 2005;37(6):09-11.

2. Saxena HO, Brahmam M. The flora of Orissa, Orissa Forest Development Corporation Ltd., Bhubaneswar: 1995;3:1720-2.

3. Singh NP, Lakshminarasimhan P. Karthikeyan S, Prasanna PV. Flora of Maharashtra State, Botanical survey of India: 2001;2:941.

4. Bakshi DN, Sensarma P, Pal DC. A lexicon of medicinal plants in India. Calcutta: Naya Prokas: 2001:194-5

5. Shashi G, Rabinarayan A. Ethnomedicinal claims of Ficus semicordata Buch.-Ham. ex Sm.: A review. International Journal of Green Pharmacy. 2018;12(1):206-13.

6. Donald JA. Plant micro techniques, Macgrow Hill Book Company, New York: London: 1940;105.

7. Trease, Evans, Pharmacognosy, 15th Ed., W.B. Sunders Company Ltd. 1996;521-47.

8. Wallis TE. Text book of Pharmacognosy. Edition $5^{\text {th }}$ New Delhi: CBS Publishers 1985; p.572-578.

9. Anonymous. The Ayurvedic Pharmacopoeia of India. Part-II. Vol-II. 1st ed. New Delhi: Government of India, Ministry of Health and Family Welfare, Department of AYUSH: 2008.

10. Kasture AV, Mahadik KR, More HN, Wadodkar SG. Pharmaceutical analysis. Nirali Prakashan: 2009;2(18).

11. Shukla VJ, Bhatt UB. Methods of qualitative testing of some ayurvedic formulations. Gujarat Ayurvedic University, Jamnagar: 2001;5-10.

12. Chase $C R$, Pratt RJ. Fluorescence of powdered vegetable drugs with particular reference to development of a system of identification. J Amer Pharm Assoc. 1949;324-31.

13. Babu K, Shankar SG, Rai S. Comparative pharmacognostic studies on the barks of four Ficus species. Turk J Bot. 2010;34:215-24

14. Metcalfe CR, Chalk L. Anatomy of the Dicotyledons, Oxford University Press, Amen House, London: 1950;1265.

15. Taha M. Sarg, Fawkeya A. Abbas, Zeinab I. El Sayed, Ahmed M. Mustafa Macro- and micromorphological study of the leaf, stem and root of Ficus retusa L.'variegata'. MJPS. 2010;26(2):1-10.

16. MA Ramadan, AS Ahmad, AM Nafady, Al Mansour. Macro-and micromorphology studies of the leaf, stem and stem bark of Ficus pandurata Hance. cultivated in Egypt. Bull Pharm Sci Assiut University. 2008;31:1-28.

17. Faiyaz Ahmed, Asna Urooj. Pharmacognostical studies on Ficus racemosa stem bark. Pharmacognosy Journal. 2011;3:19-24. 
18. Tripathi Manoj, Sikarwar RLS. Pharmacognostic studies on Plaksha (Ficus virens Ait.) stem bark. Indian Journal of Natural Products and Resources. 2015;27-32
19. Buniyamin A Ayinde and Fabian C Amaechina, Pharmacognostic and hypotensive evaluations of the stem bark of Ficus exasperata Vahl (Moraceae) Journal of Pharmacy and Bioresources 2009;6:43-9.

\section{GRAPHICAL ABSTRACT}
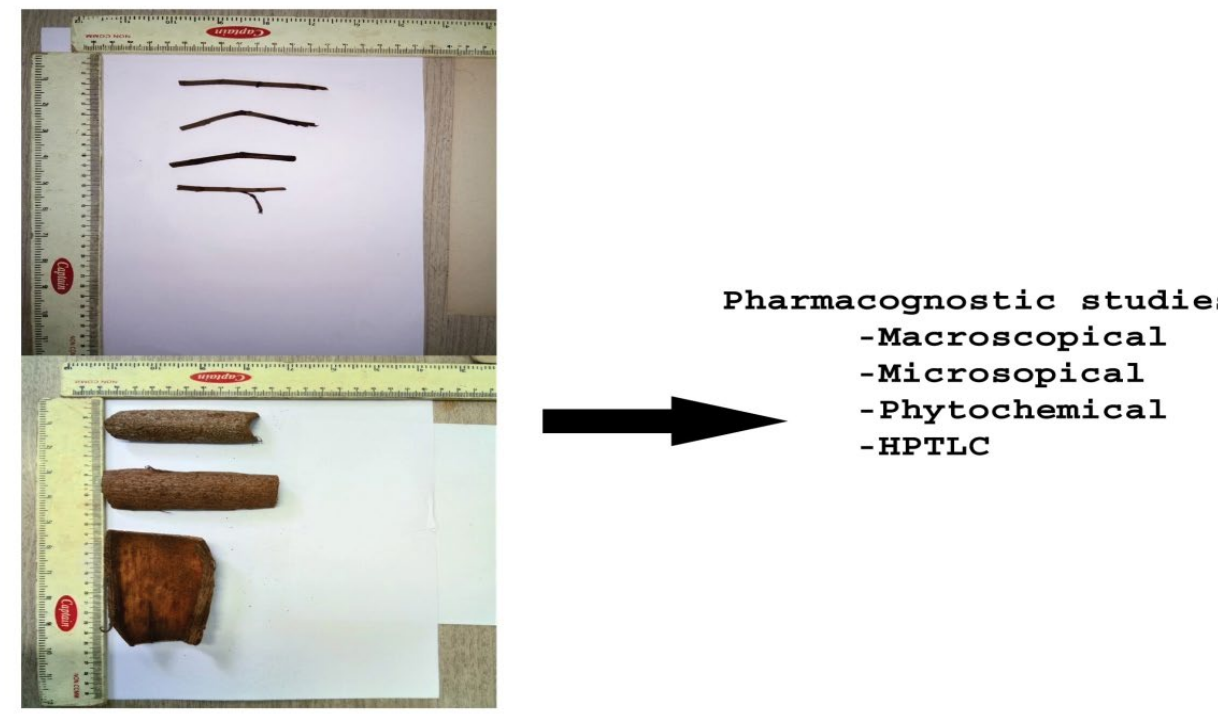

Stem And stem Bark

Ficus semicordata Buch.-Ham. Ex sm.

\section{SUMMARY}

The present study provides useful information for identification and authentication of stem and stem bark of Ficus semicordata.

Cite this article: Shashi G, Rabinarayan A, Harisha CR, Vinay S. Detailed Pharmacognostical and Phytochemical Screening of Stem and Stem Bark of Ficus semicordata Buch.-Ham. Ex sm. - An Extra Pharmacopoeial Drug of Ayurveda. Pharmacog J. 2019;11(6):1303-11. 